\title{
EL GUARDIÁN DE LA SAL. ECONOMÍA OCULTA Y CONFLICTO DE JURISDICCIÓN EN EL VALLE DE COFRENTES A MEDIADOS DEL SIGLO XVIII
}

\author{
Jorge Antonio CATALÁ SANZ \\ Universitat de València
}

\begin{abstract}
Resumen
La muerte violenta de un guardia de la real renta de salinas en un barranco de Cofrentes, en febrero de 1747, puso al descubierto la existencia de una fábrica clandestina y de una red de contrabando de sal que abastecía a numerosos conventos valencianos. Dos factores coyunturales propiciaron su aparición: las dificultades de suministro de uno de los principales alfolíes reales y el impuesto extraordinario fijado sobre el precio de la sal con motivo de la guerra de Sucesión austríaca. Pero, al margen de ello, el caso revela las carencias estructurales del aparato de vigilancia y las contradicciones entre los distintos ámbitos jurisdiccionales implicados, que hicieron posible la articulación de un sistema de producción y comercialización en el que se integró una parte significativa de la población de Cofrentes, así como la generación ilícita de un importante volumen de renta. Estas páginas tratan de dichas actividades económicas ocultas y del desafío que su punición planteó a la administración señorial.
\end{abstract}

Palabras clave: Contrabando, Sal, Economía Sumergida, Conflicto de Jurisdicción, Solidaridades Vecinales, Redes Sociales, Administración Señorial.

\begin{abstract}
The Keeper of the Salt. Hidden economy and clash of jurisdiction in the Valley of Cofrentes in the mid XVIIIth Century.

In February 1747, the violent death of a Royal Saltworks keeper at the hands of some neighbours of Cofrentes exposed a clandestine saltwork and a smuggling net that
\end{abstract}

1. Este trabajo se inscribe dentro del proyecto de investigación sobre «Los conflictos generados por la abolición de los fueros en la sociedad valenciana del siglo XVIIl) (GV05/072), financiado por la Conselleria d'Empresa, Universitat i Ciència de la Generalitat Valenciana. 
had been supplying a large number of monasteries all over Valencia with illegal salt. This smuggling net was encouraged by two facts: on the one hand, the downturn in production in one of the main Valencian Royal Saltworks; on the other hand, by a special tax imposed on the sale of salt during the War of the Austrian Succession. Nevertheless, this case also brings to light the defects of the coercive apparatus and the contradictions between the different jurisdictions concerned that made it possible not only to create a system of production and commercialization in which an important part of the village was engaged, but also to generate large quantities of illegal income. These pages deal with those hidden economic activities and the challenge that its punishment involved for the seigneurial administration.

Key words: Smuggling Net, Salt, Hidden Economy, Clash of Jurisdiction, Neigbourhood Solidarities, Social Networks, Seigneurial Administration.

En virtud del monopolio regio sobre la producción y comercialización de la sal, pieza relevante de la reforma fiscal que siguió a su victoria en el conflicto sucesorio, ${ }^{2}$ Felipe V decretó, en 13 de enero de 1712, que se incorporase al real patrimonio la salina que el duque de Gandía poseía en su señorío de Cofrentes, asignándole en recompensa la renta perpetua que se estimase adecuada, tal y como se había practicado ya con las salinas pertenecientes a particulares en el reino de Aragón. Un mes más tarde, José Pedrajas, superintendente general de las rentas reales del reino de Valencia, envió a Cofrentes al visitador Carlos Coluchi con orden de tomar posesión de dicha salina y destruirla por completo al objeto de que los vecinos no pudiesen servirse de ella, pues, según sus cálculos, el producto que podía obtenerse era moderado y los gastos de administración crecidos. ${ }^{3}$ En marzo, Coluchi terminó de ejecutar lo dispuesto: arruinó el manantial de agua salada, cegó las balsas y derribó el pozo y la casa anexas, encargando al alcalde y regidores de la villa que impidiesen su recomposición, bajo pena de 500 pesos. $^{4}$

En realidad, tantas prevenciones eran inútiles, ya que la antigua salina ducal era sólo una de las diversas fuentes salíferas del extenso término de Cofrentes, ${ }^{5}$ de manera

2. La renta de salinas se convirtió en una de las principales fuentes de ingresos de la Tesorería del Ejército en territorio valenciano, por detrás de los dos pilares básicos de la Real Hacienda: el equivalente y el estanco del tabaco. Véase R. FRANCH BENAVENT y V. GIMÉNEZ CHORNET, «Una aproximación a la gestión territorial de la Real Hacienda: las cuentas del Tesorero del Ejército de Valencia (1751-1807)», en Estudis, 29 (2003), pp. 105-129.

3. La medida encaja perfectamente con la pauta «quirúrgica» seguida por Pedrajas en su gestión al frente de la superintendencia, que se caracterizó por la drástica supresión de cargos y la subsiguiente reducción de costes salariales. Cfr: R. FRANCH BENAVENT, «El cambio de naturaleza de las rentas de la Generalitat valenciana tras la abolición de los fueros: la reacción del clero en defensa de su inmunidad y los conflictos provocados por la gestión de los intendentes》, en Estudis, 31 (2005), p. 276. Véase también S. VILLAMARÍn GómEZ, La Generalitat valenciana en el siglo XVIII. Una pervivencia foral tras la Nueva Planta. Valencia, 2005, pp. 80-85.

4. Finalmente, por real orden dada en Madrid en 26 de septiembre de 1713, la recompensa perpetua a los duques de Gandía quedó fijada en 440 libras anuales. (AHN, Nobleza, Osuna, Leg. 989, $I^{1-3}$ ).

5. J. Hermosilla PLA (dir), El patrimonio del agua en el valle de Ayora-Cofrentes, Valencia, 2002, pp. 175-201. 
que no era difícil para los habitantes del lugar proveerse de sal para su propio consumo al margen de los alfolíes reales. ${ }^{6}$ Más arriesgado era comerciar con ella, dado que la posibilidad de ser descubiertos aumentaba considerablemente. No obstante, dos factores vinieron a aunarse tres décadas después de la clausura de la «real fábrica» nonata para propiciar la creación de una red de contrabando a gran escala en aquel confín del reino. Por un lado, el sobreprecio de 13 reales por fanega establecido por la corona con ocasión de la guerra de Sucesión austríaca y que se prolongó hasta 1749 , crecimiento de tal magnitud que de inmediato dio lugar a numerosos fraudes. ${ }^{7}$ Tan problemática debió ser su cobranza, que en la escritura de recudimiento otorgada en 1744 a favor de los arrendatarios del impuesto se les autorizó a minorar su cuantía allí donde lo creyeran oportuno. ${ }^{8}$ Por otro lado, el descenso alarmante -verificado al menos desde 1743- de la producción de sal en la fábrica de Manuel, que abastecía a más de un centenar de poblaciones desde el valle de Ayora-Cofrentes hasta el de Albaida, lo que motivó sendas investigaciones para esclarecer no sólo las causas de semejante anomalía, sino también las razones por las que no se suplían los correspondientes acopios en el alfolí de la Mata de Cullera. ${ }^{9}$

Las páginas que siguen se basan en la causa abierta por la intendencia en 1747 al descubrirse la existencia de una fábrica de sal clandestina en Cofrentes. El proceso así substanciado proporciona información -indiciaria e incompleta, pero no por ello menos valiosa-- sobre un fenómeno del que, por su propia naturaleza, rara vez se halla rastro documental, especialmente en los archivos señoriales; la generación de renta en una comunidad rural a través de actividades económicas ocultas, invisibles. Aunque tambićn valdrían otros adjetivos (sumergidas, en la sombra, ilegales) para caracterizar el conjunto de actividades industriales y mercantiles a que dio pie la salina de Cofrentes, empleo éstos con la intención de diferenciarlas de aquellas actividades marginales o periféricas que, como la caza y la pesca, la utilización de recursos forestales, la alimentación del ganado en zonas reservadas o la venta al por menor, estaban más o menos reguladas por la administración señorial y permitían a los miembros de una comunidad agraria diversas formas de aprovechamiento: desde completar la dieta hasta redondear los ingresos en metálico de la familia. Lo que distingue este caso de otros fraudes habituales en las economías señoriales (tala de árboles, apacentamiento de ganado en dehesas, hurto de hierbas, ocultación de cosechas, etc... $)^{16}$ es, en primer

\footnotetext{
6. Algo frecuente en las poblaciones más próximas a las salinas. Véase el ejemplo de Rute en B. GARCíA IIMÉNeZ, "La sal en el siglo XVIII. Presión fiscal a través del abasto en Rute», Andalucia Moderna (II). Actas del Ir Congreso de Historia de Andalucia, Córdoba, 1995, pp. 327-335.

7. M. ArTola, La hacienda del Antiguo Régimen, Madrid, 1982, p. 290.

8. ARV, Procesos de Intendencia, $3288,69 \mathrm{v}-78 \mathrm{v}$.

9. ARV, Procesos de Intendencia, 1966 y 2288.

10. Sin salir de los dominios de la casa de Gandía en el siglo XVHI, valgan como ejemplo los numerosos pleitos por impago de derechos señoriales incoados en el ducado de Gandía y el marquesado de Llombai. Cfr. I. MORANT, El declive del señorío, Valencia, 1984, pp. 196-201; M. ARDIT, Creixement económic i conflicte social. La foia de Llombai entre els segles XIII i XIX, Catarroja-Barcelona, 2004, pp. 525-530.
} 
lugar, que la generación ilícita de renta se hizo a costa de una regalía de la corona: el estanco de la sal, por lo que su repercusión fiscal y penal era mucho mayor. Baste decir que la cédula de penas expedida en 5 de febrero de 1728 contra los defraudadores de la renta de salinas castigaba con seis años de galeras al plebeyo que sacase sal de arroyos y manantiales salobres. "En segundo lugar, lejos de responder a una estrategia de supervivencia individual o a la ocasional voluntad transgresora de una minoría de sujetos, el contrabando de sal adquirió en Cofrentes un carácter verdaderamente colectivo, hasta el punto de constituirse un sistema de producción y comercialización articulado y consensuado, que incluía la ordenación del trabajo, la regulación de precios-explícita, mediante acuerdo verbal- y la asignación de zonas de distribución y venta (implícita e informal, pero, en lo esencial, igualmente respetada), un sistema protegido por un generalizado «pacto de silencio» para evitar que el delito, pese a hacerse a plena luz, se hiciera visible. Por último, no creo que, en rigor, pueda considerarse marginal, residual o periférica la actividad de los fabricantes de sal de Cofrentes, por cuanto ésta llegó a ser la ocupación principal de la mayoría de ellos, bien porque no poseían más medios de producción que su capacidad de trabajo, bien porque resultaba más rentable concentrar sus energías en la elaboración de sal que en la explotación de sus tierras.

Aun cuando el contrabando suponía una amenaza tan seria para la economía y el orden público que la administración señorial hubo de cooperar activamente con la corona en la represión de un crimen que mermaba los ingresos y cuestionaba la autoridad de una y otra, ${ }^{12}$ el caso de Cofrentes muestra que el surgimiento de tal red de contrabando fue posible precisamente gracias a las deficiencias del aparato de inspección y a la incompleta delimitación del reparto de responsabilidades coactivas entre los distintos ámbitos jurisdiccionales. El hecho de que el visitador Coluchi delegase en las autoridades municipales la evitación de nuevas extracciones de la vieja salina ducal luego de incorporarla al patrimonio regio en 1712 es ya sintomático de la escasez de recursos de control de la Real Hacienda. No sólo eso. Hacer recaer esta labor de vigilancia suplementaria sobre el alcalde y los regidores de la villa suponía olvidar el cúmulo de tareas de prevención ordinarias que tenían encomendadas. Por mor de la síntesis, conviene traer a colación el extracto de obligaciones que Antonio Vicente Ximénez del Olmo, gobernador del marquesado de Llombai, propio también de los duques de Gandía, impuso en 1725 a los ayuntamientos bajo su control: «las justicias y regidores, así mayores como menores sin distinción, visiten con frecuencia las carnicerías, panaderías, tiendas y demás casas de comercio, comprueben los pesos y medidas y los corrijan, reconozcan los géneros...» y «ronden de noche por el poblado y huerta, siendo necesario por ser obligación de sus oficios que ninguno ha cumplido hasta ahora, y tengan presente que los gobernadores no pueden soportar este trabajo y

11. Novisima recopilación de las leyes de España. Libro IX, Título XIX, Ley II.

12. Son muy pertinentes las observaciones al respecto del contrabando y la oposición antiseñorial de $M$. ORTEGA LÓPEZ, «Algunas formas de protesta antiseñorial en la España de la segunda mitad del siglo XVIII», en E. SARASA Sánchez y E. Serrano Martínez (eds.), Señorio y feudalismo en la península ibérica, Zaragoza, 1993, vol. II, pp. 425-433. 
asistir a los tres pueblos con sus ministros». Como apostilla Manuel Ardit, demasiadas responsabilidades para simples labradores que, además de tener asuntos particulares que atender, no cobraban por sus cargos. ${ }^{13} \mathrm{El}$ corolario es perfectamente aplicable al valle de Cofrentes, cuyos cinco ayuntamientos (Cofrentes, Zarra, Teresa, Jarafuel y Jalance) fueron residenciados en 1726 por el mismo Ximénez del Olmo, multados de resultas con 574 libras y obligados a observar, a partir de 1731, unos «capítulos de buen gobierno» que regulaban con detalle -constan de 68 artículos- la gestión y vigilancia de tiendas, panaderías, carnicerías, hornos, molinos, acequias, cultivos, bosques, herbajes, caza, ganado, orden público, contratos mercantiles, normas de convivencia, juegos de azar, etc... ${ }^{14}$

Como se desprende de las últimas palabras del gobernador de Llombai, no puede decirse que la administración señorial, tercer vértice del aparato fiscalizador, estuviera sobrada de medios. Igual que sucedía en otros grandes dominios señoriales sujetos a la lógica de la centralización del poder y el absentismo de su titular, ${ }^{15}$ en el estado de Cofrentes la gestión de la potestad estaba confiada a un gobernador y un reducido grupo de personas más o menos cualificadas. En los años en que se produjo el fraude contra la Real Hacienda, el gobernador del valle tan sólo tenía a su servicio un escribano, una ronda mínima, formada por un alguacil y un alguacil de monte, y cinco colectores de rentas (uno para cada una de las villas), a los cuales correspondía cobrar los censos de casas y tierras, recoger las particiones de cosechas, diezmar frutos - para lo cual contaban con la asistencia de los respectivos curas párrocos, a los que pagaban por anotar los asientos en los «contralibros»-, percibir los luismos, arrendar las regalías y herbajes que no se reservara para sí la señoría, cuidar los graneros y las bodegas, vender los frutos al precio fijado por el gobernador o el procurador general de los duques, y dar cuenta y razón formal de todos los valores. ${ }^{16}$

Sin embargo de las multas impuestas en 1726 y de la repetición de residencia en $1733,{ }^{17}$ tampoco parece que la administración señorial lograse incrementar de forma sustancial la eficacia de la gestión municipal y de la recaudación de impuestos mediante juicios de residencia más o menos periódicos y la eventual publicación de «capítulos de buen gobierno». En su estudio del funcionamiento de tales mecanismos en las tierras de la casa del Infantado, Adolfo Carrasco demuestra que, pese a la identidad

13. M. ARDIT, op. cit., pp. 25 I-252.

14. J. V. POVEDA Mora, Historia de Ayora, Cofrentes, Jalance, Jarafuel, Teresa de Cofrentes y Zarra. Las crisis del siglo XVII, La expansión del XVIII y la edad moderna en el Valle de Ayora-Cofrentes, Valencia, 2003 , pp. $77-78$ y $540-543$.

15. Un buen ejemplo es el del ducado de Feria, cuyos gobernadores apenas contaban con el auxilio de una treintena de personas para administrar un territorio poblado por 20.000 habitantes. S. ARAGÓN MATEOS, El señor ausente. El señorio nobiliario en la España del Setecientos. La administración del ducado de Feria en el siglo XVIII, Lleida, 2000. Para una visión general y completa del problema, véase B. YUN CASAlilla, La gestión del poder. Corona y economías aristocráticas en Castilla (siglos XVI-XVIII), Madrid, 2002.

16. AHN, Nobleza, Osuna, Leg. 988, 7. ARV, Protocolos de Juan Teruel, 3472, $71 \mathrm{v}-78 \mathrm{v}$.

17. I. MORANT, op. cit., p. 197; J.V. POVEDA MORA, op. cit., p. 78. 
de intereses entre el soberano y el dueño de vasallos ante los concejos, los jueces eran incapaces de resolver un problema de índole estructural, agravado allí donde las oligarquías locales conseguían instrumentalizar el ayuntamiento en beneficio propio. ${ }^{18}$ No pretendo afirmar con ello que la señoría viera amenazado su dominio (aunque lo cierto es que los cinco ayuntamientos del valle de Cofrentes solicitaron -sin éxito- la reversión a la corona en 1757), ${ }^{19}$ ni que tropezara con dificultades insalvables para percibir sus rentas y detraer su parte del excedente agrario, como no las encontró el conjunto de la nobleza señorial valenciana a lo largo del siglo XVIII. ${ }^{20}$ Tan sólo que, dadas las circunstancias descritas, a los duques de Gandía les interesaba, como es obvio, evitar la confrontación directa con sus vasallos y tentar, siempre que fuera posible, estrategias de control basadas en la integración y el consentimiento, mediante las vías conocidas: ${ }^{21}$ fomento de adhesiones y creación de clientelas (entre los empleados de la casa ducal y los arrendatarios de regalías en el valle de Cofrentes se repiten los nombres de algunas familias), reparto de limosnas (como las que se distribuyeron entre los pobres de sus estados tras la muerte del duque Luis Ignacio Francisco de Borja en 1740), patronazgo religioso, concesión de gracias y mercedes, etc...

Sin ánimo de adelantar conclusiones, es desde esta perspectiva paternalista que conviene analizar la actuación del gobernador, máxima autoridad delegada de la señoría, en la investigación y sanción penal del fraude contra la Real Hacienda. La documentación que se conserva no permite aclarar si Luis Clavijo y Valenzuela, gobernador y justicia mayor del valle de Cofrentes desde que María Ana de Borja sucedió a su hermano Luis Ignacio en la posesión de sus títulos y estados en 1740, supo o no de la existencia de la red de contrabando de sal en cuanto ésta tomó cuerpo, por más que algunos testimonios así lo indiquen. No obstante, sí puede afirmarse que su conducta respondió a una pauta paternalista, pues, como se verá, el gobernador trató de castigar a los contraventores a fin de proteger a la comunidad, como un padre que escarmienta a sus hijos díscolos por haber puesto en peligro al resto de la familia. Este componente paternalista es más notorio si se compara su manera de proceder con la del juez de comisión designado al efecto por la intendencia que, lejos de diluir el conflicto, procu-

18. A. CARRAsco Martinez, Control y responsabilidad en la administración señorial: los juicios de residencia en las tierras del Infantado (1650-1788), Valladolid, 1991.

19. La demanda fue finalmente desestimada en 1762. Cfr. J. V. POVEDA MORA, op. cit., p. 92

20. J. A. CATALÁ SANZ, Rentas y patrimonios de la nobleza valenciana en el siglo XVIII, Madrid, 1995, pp. 228-232.

21. Ignacio ATIENZA HERNÁNDEZ ha estudiado esta cuestión en varios trabajos, a los cuales me remito: «Pater familias, señor y patrón: æconómica, clientelismo y patronato en el Antiguo Régimen», en PASTOR REYNA (comp.), Relaciones de poder, de producción y parentesco en la Edad Media y Moderna. Madrid, 1990, pp. 411-458; «El señor avisado: programas paternalistas y control social en la Castilla del siglo XVIL», en Manuscrits, 9, 1991, pp. 155-204; «Consenso, solidaridad vertical e integración versus violencia en los señoríos castellanos del siglo XVIII y la crisis del Antiguo Régimen», en E. SARASA SÁNChEZ y E. SERRANO MARTínez (eds.), Señorio y feudalismo en la peninsula ibérica, Zaragoza. 1993, vol. II, pp. 275-318. 
ró, en aras de la reparación de la ofensa a la corona, aplicar la ley penal hasta sus últimas consecuencias (al menos hasta que tuvo conciencia de cuáles podían ser éstas).

Una última observación antes de adentrarme en el caso. He optado por relatar los hechos tal y como se presentan en los autos substanciados por las justicias que tomaron parte en la averiguación del delito, lo que no quiere decir -espero que así se entienda- que eluda el análisis ni renuncie a hacer las debidas inferencias (quién sabe si excesivas) cuando lo crea conveniente. Primero por el deseo (y el placer) de inducir en quien lea estas páginas la intriga y la sorpresa que la lectura del proceso me produjo. Segundo con la finalidad de que se aprecie con la mayor claridad posible la diferencia de criterios entre los ámbitos jurisdiccionales en disputa. $Y$ tercero porque considero relevante para la comprensión de las relaciones y tensiones sociales -verticales y horizontales, entre la administración señorial y sus vasallos y entre los propios vecinosque se adivinan bajo la tramoya judicial la narración de las diligencias practicadas y la reproducción de los testimonios más significativos tomados por uno y otro jueces.

\section{1.-DOS CADÁVERES JUNTO A LAS FUENTES SALOBRES}

Era medianoche cuando Nicolás Hernández, regidor mayor de Cofrentes, llegó a la residencia del gobernador en Zarra para comunicarle el hallazgo de dos cadáveres en el barranco del Martinete, en la partida de la Chirrichana. Sobresaltado por la noticia, Luis Clavijo convocó al escribano Tomás Carbonell y a su alguacil y, tan pronto como estuvieron listos, emprendieron camino hacia la villa de Cofrentes, a la que arribaron cuatro horas después, a las siete de la mañana del 22 de febrero de 1747.

El gobernador y su comitiva, a la que se unieron varias personas en la localidad, se demoraron algunas horas más en recorrer el par de leguas que median entre ésta y el barranco, próximo al río Cabriel. No fue difícil localizar los cadáveres. El primero yacía boca abajo y presentaba cuatro heridas penetrantes en la cabeza. De las faltriqueras le asomaba un rosario y en la bolsa de badana que llevaba consigo había un título que identificaba al finado como Ginés García, vecino de Alcalá del Río, guardia de la real renta de la sal, con firma del intendente marqués de Malespina. En el suelo, a un palmo de la cabeza, dos piedras de media arroba y un garrote de almez ensangrentados. El segundo muerto, identificado por los testigos como Cristóbal Correcher, vecino de Cofrentes, se hallaba a 850 pasos de distancia cuesta arriba, en lo alto del barranco. En su pecho izquierdo, sobre el corazón, se apreciaba una herida de arma de fuego a través de la camisa quemada por la pólvora. No muy lejos de allí, frente a unas balsas de agua salobre, encontraron 19 panes de sal y otras tantas sartenes. Acabada la inspección del lugar, el gobernador ordenó arrojar los panes de sal al agua, quemar los montones de leña que alimentaban las hornillas y cegar las balsas, depositando en poder del escribano las sartenes y otros enseres hallados. ${ }^{22}$

22. ARV, Procesos de Intendencia, [457. Ramo $3^{\circ}$, I r-3 r. (Los ramos no aparecen numerados por orden cronológico). 
De regreso a Cofrentes, casi de anochecida, Clavijo mandó comparecer ante sí al médico y al cirujano de la villa para que reconocieran los cadáveres. Luego de su examen, que confirmó que las heridas que presentaban eran mortales de necesidad, tuvo aún tiempo de tomar declaración al alguacil mayor Juan García y a Francisco Correcher, quienes dijeron que la noche antes, por orden del regidor mayor, y mientras éste se trasladaba a Zarra, habían acudido con otros hombres armados al lugar de los hechos para custodiar los cadáveres, que encontraron velados por Cristóbal García y Bernabé de Aba, moradores de la aldea de Casas del Río. ${ }^{23}$ Es posible que contasen también al gobernador lo que sabían de los difuntos y que éste les sonsacara los pormenores de la conversación mantenida con sus veladores, pero nada de esto fue consignado por el escribano. Es probable, igualmente, aunque tampoco quedase escrito en sitio alguno, que, por la información que Nicolás Hernández y otros miembros de su séquito le habrían proporcionado de forma oficiosa, antes de acabar el día Clavijo supiese ya lo suficiente sobre la causa de las muertes, las circunstancias en que se habian producido, y, lo que era más importante, los problemas que subyacían bajo el doble crimen como para hacerse una idea aproximada del alcance del asunto, así como de las consecuencias que podía tener no ya para los directamente implicados en el mismo, sino para la villa entera. Quizá incluso decidiera esa misma noche hasta dónde convenía llegar en el esclarecimiento de los hechos.

Al día siguiente, después de dar sepultura a los muertos en el vaso común de la iglesia parroquial, el gobernador continuó sus pesquisas con sigilo. Primero hizo prestar declaración al regidor mayor Hernández, que explicó que la tarde del día de autos, por hallarse ausente el alcalde Pedro Muñoz, fueron a decirle que Benito Soriano, morador de Casas del Río, había dado aviso de que en el barranco del Martinete había dos hombres muertos, enterado de lo cual envió a dicho paraje al alguacil mayor con orden de guardarlos y de «que no llegase nadie ni tocase cosa alguna de lo que en él encontrasen». Preguntado por el motivo de las muertes y sus ejecutores, Hernández se limitó a contestar que creía que el citado Soriano y Cristóbal García sabrían dar cuenta de cómo había sucedido el lance, de modo que Clavijo los hizo llamar. ${ }^{24}$

Aunque esconde varias cartas en la manga -mas no es el único en hacerlo en esta partida de naipes marcados-, el relato de Cristóbal García, primero de ambos testigos presenciales en declarar, permite reconstruir los acontecimientos del 21 de febrero. Aquella mañana, armado con un trabuco y una escopeta, el guardia de la renta de salinas Ginés García se había presentado en Casas del Río para procurarse compañía a fin de inspeccionar el barranco del Martinete, donde tenía noticia de que se fabricaba sal de contrabando. Para vencer la resistencia del declarante y de Benito Soriano, Ginés invocó un mandato del gobernador del valle que le autorizaba a reunir en su auxilio hasta treinta hombres, amenazándolos con graves perjuicios si se negaban. Al aproximarse a dicho paraje, Ginés y sus atribulados acompañantes comprobaron que, en efec-

23. Ibidem, 3 v $-8 \mathrm{r}$.

24. Ibidem, $10 \mathrm{r}-1 \mathrm{I} \mathrm{v}$. 
to, había algunos individuos haciendo sal. Éstos se dispersaron en cuanto se percataron de su llegada, dejando libre el acceso hasta las fuentes salíferas. En torno a éstas, el improvisado trío pesquisidor encontró diferentes pilones de sal y las sartenes empleadas en su fabricación. Después de un somero registro, el guardia urgió a Soriano a que fuese en busca de un par de caballerías para incautarse de todo el material, momento que aprovecharon los salineros furtivos para retornar a lo hondo del barranco. Eran ocho, todos vecinos de Cofrentes y, por ello, conocidos del testigo: los hermanos José y Juan Gómez, de 22 y 24 años, ambos solteros; Francisco Alarcón, alias Panadero, de 21 años; Francisco Ródenas, apodado el Gilo, de 18 años; Juan Alarcón, llamado el Grillo, un año más joven que éste; Cristóbal Correcher, mozo soltero; José de Sotos, alias el Jornal, de 30 años, casado; y Diego García, también casado (y quizá el mayor de todos).

Correcher encabezaba el grupo cuando, entre súplicas, empezaron a acercarse a Ginés rogándole que al menos les devolviera las sartenes. Al calor de la discusión, y temiendo que se abalanzaran sobre él para recobrar sus útiles, el guardia amartilló el trabuco y encaró a los furtivos. Entonces sobrevino la tragedia. En la riña disparó su arma sobre el pecho de Correcher, que cayó fulminado a sus pies. Encorajinado por la muerte de su compañero, el Gilo acertó a asestarle al guardia un golpe en la cabeza con un palo que llevaba. Con el rostro ensangrentado, la testa rota, Ginés echó a correr como pudo barranco abajo hacia el río, sintiendo el aliento de sus perseguidores en la nuca. Llegado a este punto de su declaración, Cristóbal García afirma recordar tan sólo que, temiendo por su vida, presa del pánico, escapó a toda prisa, abandonando a su suerte al guardia malherido, hasta que tropezó en el camino con Soriano y Bernabé de Aba, que volvían con sendos mulos al barranco para trasladar los enseres aprehendidos. Después de contarles lo ocurrido, decidieron aventurarse a indagar qué le había pasado a Ginés. No lejos hallaron su cuerpo, rodeado por el Gilo y otros tres salineros, que, angustiados, confesaron haber matado al guardia, de todo lo cual fue a dar cuenta Soriano al cura y a la justicia de Cofrentes. ${ }^{25}$

Oído el testimonio de Cristóbal García, el gobernador dictó auto de prisión y embargo de bienes de los citados fabricantes, así como de Cristóbal Villena, que también había sido visto rondando las balsas salobres del Martinete aquella mañana. Ninguno de los ocho imputados fue hallado en su domicilio. Al ser preguntados, sus familiares manifestaron desconocer dónde paraban desde hacía días. Para el logro de su captura, Clavijo ordenó despachar requisitorias a las justicias de los lugares próximos, tanto en Castilla como en Valencia. Antes de irse a la cama mandó que se remitiera relación de los hechos a Diego de Morales, fiscal de la Real Audiencia, para que éste informara a la Sala del Crimen. ${ }^{26}$ Sin embargo, no creyó oportuno comunicar el suceso al intendente Malespina, a quien cabía privativamente la jurisdicción sobre la renta de la sal. De hecho, aún se demoraría algunos días más en hacerlo.

25. Ihidem, $11 \mathrm{v}-14 \mathrm{r}$.

26. Ibidem, $14 \mathrm{v}-16 \mathrm{r}$. 
El segundo acompañante del guardia, Benito Soriano, prestó declaración el día 24. Su narración difiere de la de Cristóbal García en dos puntos relevantes. Por un lado, afirma que antes que Ginés le ordenase traer un par de caballerías para recoger las pruebas incautadas consintió que los salineros recuperasen los zurrones con comida que habían abandonado en el lecho del barranco. Esto pudo inducirles a pensar que el guardia no estaba determinado a denunciarlos y que, tal vez, podían persuadirlo de que no aprehendiese sus sartenes, únicos bienes que algunos de ellos, pobres de solemnidad, poseían. Por otro lado, agrega que al encontrarse, de vuelta al barranco, con Gilo y los otros tres matadores del guardia, ${ }^{27}$ éstos, conscientes de que acababan de arruinar sus vidas, trataron de deshacerse del finado lanzándolo al río, lo que impidieron el testigo y sus compañeros: Bernabé de Aba y Cristóbal García, ya que en ese caso se les achacaría a García y a él mismo su desaparición, pues habían sido vistos con Ginés en Casas del Río. Por esa razón Aba y García permanecieron en el barranco guardando sus restos mortales mientras Soriano marchaba a Cofrentes a dar aviso de lo sucedido. La atestación de Bernabé de Aba, tomada inmediatamente después, ratifica por entero lo dicho por Soriano.

El gobernador Clavijo no interrumpió la investigación y regresó a su residencia en Zarra hasta el 1 de marzo, una semana después de su llegada a Cofrentes. El embargo de bienes de los reos, efectuado el 24 de febrero, confirmó la pobreza de la mayoría de ellos. Salvo Francisco Alarcón y Diego García, dueños de pequeñas parcelas de tierra, y Cristóbal Villena, propietario de la casa donde moraba, ni el difunto Correcher ni los demás salineros furtivos poseían bienes propios. Ni siquiera los tenía José de Sotos, casado con María Navarro, con la que convivía gracias a la caridad paterna. Los testigos interrogados en los días siguientes no aportaron grandes novedades. Tan sólo dos de ellos, Cristóbal Martínez y Salvador Salinas, que habían formado parte de la comitiva inicial del gobernador, incriminaron a nuevos reos en la fabricación clandestina de sal: Melchor López, un pequeño enfiteuta de 38 años, y su hijastro Esteban Cañas, de 18, que, de acuerdo con sus declaraciones, habrían acudido al barranco del Martinete el día de autos. Pero, al igual que el resto de imputados, nadie supo dar cuenta de su paradero cuando los alguaciles y el escribano fueron a prenderlos. Por lo demás, su testimonio corrobora el arrepentimiento inmediato de los reos. Así lo expresa Cristóbal Martínez, que asevera haber oído que los ejecutores de Ginés García «se veían perdidos, pues, habiendo muertes, no podian ya parar por estas tierras》.$^{28}$

No pudiendo retrasarse por más tiempo, el 27 de febrero Clavijo escribió por fin al intendente para referirle los sucesos acaecidos en Cofrentes. ${ }^{29}$ Un día después

27. En su declaración ante el gobernador, Soriano dice que estos tres hombres eran Francisco Alarcón, Juan Gómez y José de Sotos. (Ihidem, 18 v). No obstante, al ofrecer testimonio ante el juez Pardo de la Casta afirmará que el tercero de ellos era Juan Alarcón. (Ramo $2^{\circ}, 32 \mathrm{v}$ ).

28. Ramo $3^{\circ}, 22 \mathrm{r}-33 \mathrm{r}$.

29. La carta no figura en los autos, por lo que es imposible saber la versión de los hechos que ofreció el gobernador al intendente. La fecha de la misma se conoce por la respuesta del marqués de Malespina, de 2 de marzo, que sí aparece adjunta. (Ibidem, $37 \mathrm{r}$ ). 
recibió la -cabe suponer-anhelada respuesta del fiscal de la Audiencia, firmada el 25, en que le instaba a continuar con la causa con la mayor actividad, haciendo uso de su jurisdicción y obrando en todo conforme a derecho, con la obligación de consultar la sentencia con los jueces de la Sala del Crimen. Sólo entonces se animó a restituirse a su domicilio en Zarra, dejando encomendado al alcalde y demás oficiales de Cofrentes que persistieran en el logro de la prisión de los culpados. ${ }^{30}$

De momento, Clavijo podía sentirse satisfecho. Desde el principio había actuado con solicitud, procurando resolver los crímenes de la forma más breve posible. Si hasta entonces había ignorado lo que venía ocurriendo en el barranco del Martinete desde hacía tiempo, o, cuando menos, el verdadero alcance de la trama delictiva, no cabe duda de que había sabido reaccionar con presteza al tener constancia de que algunos de sus administrados se las habían ingeniado para defraudar a la Real Hacienda fabricando sal de contrabando, con cuyo producto, poco o mucho, mitigar sus estrecheces y aliviar sus vidas. Las diligencias practicadas en las primeras horas y la discreción con que luego condujo sus pesquisas sugieren que el gobernador ató más cabos de los que se reflejan en sus autos, pero en apariencia -y en este caso era particularmente importante salvar las apariencias, pues de lo contrario podían seguirse graves daños para los habitantes de aquel rincón del valle y, por qué no reconocerlo, para su propio crédito como gestor y justicia mayor del señorío-, su modo de proceder había sido intachable. Los resultados, tangibles, daban fe de su eficacia. Apenas había necesitado un día para poner en claro los homicidios e identificar con precisión a sus autores. En las jornadas siguientes, y sin llegar a cumplirse una semana, había tomado declaración a una docena de testigos, elevado a diez los culpados, embargado sus bienes y enviado requisitorias de prisión a las poblaciones de su jurisdicción y de las comarcas cercanas, de Requena a Valencia y de Jorquera a Tous. La carta del fiscal Diego de Morales en que le confiaba la continuación de la causa venía a confirmar la exactitud de su conducta.

Por lo que a la reconstrucción de los hechos se refiere, a tenor del conjunto de actuaciones procesales, de los testimonios reunidos y del énfasis puesto en algunos aspectos de los mismos, parece evidente que el gobernador trató de presentar el doble crimen como una desdichada sucesión de accidentes. Así, en su afán de novato por acabar con el fraude al regio patrimonio, Ginés García, que llevaba poco más de un mes como guardia (su título estaba fechado el 12 de enero ${ }^{31}$ ), habría perdido los nervios al verse rodeado por los defraudadores, en su mayoría pobres campesinos sin más bienes que las ropas que llevaban puestas y los utensilios que empleaban para fabricar la sal, hiriendo de muerte a uno de ellos. Los más jóvenes, los conocidos como el Gilo, el Grillo y el Panadero, sintiendo hervir la sangre por la pérdida de su compañero, habrían respondido con violencia, cegados por la ira, agrediendo al guardia con palos y piedras hasta quitarle la vida. De inmediato se habían arrepentido de su acción, sabedores de

30. Ibidem, $34 \mathrm{r}-35 \mathrm{v}$.

31. Ramo $4^{\circ}, 10 \mathrm{r}$. 
que tendrían que escapar de allí y que quizá no volverían a ver a sus familias. Si lograba capturarlos, Clavijo se encargaría de darles el merecido castigo.

Con todo, hay razones para sostener que el esmero puesto por el gobernador en llegar a la conclusión del asunto con prontitud, así como la insistencia en destacar algunas circunstancias que concurrían en el caso en detrimento de otras, ocultaban su deseo de atenuar la magnitud de los efectos penales de la averiguación, previsiblemente mayores cuanto más se prolongase y afinase ésta. No faltan indicios para formular este juicio. Ante todo, cabe preguntarse por qué tardó tantos días en informar de lo sucedido a la intendencia, a la que, según la ley, tocaba el conocimiento de las causas criminales relativas a la real renta de salinas. A mayor abundamiento, es harto sorprendente que ordenase destruir las pruebas halladas junto a los manantiales de agua salada: los pilones de sal cuajada, las hornillas para su cocción, las balsas o pozas donde secarla, etc... que podían dar una idea aproximada de la entidad de la fábrica de sal y de la gente que en ella se empleaba. En otro orden de cosas, no es menos llamativo que dejase de interrogar a los parientes de los imputados sobre las tareas en que éstos venían ocupándose en los últimos tiempos, así como a las autoridades de la villa acerca de las medidas de vigilancia tomadas para evitar el fraude. Asimismo, parece extraño que el gobernador no indagase por qué conducto había sabido Ginés García que en el barranco del Martinete había una fábrica de sal clandestina, máxime por cuanto, como Cristóbal García había hecho constar en su declaración, el guardia «traía orden de su merced para sacar aunque se le ofreciesen treinta hombres», de lo que se infiere que el gobernador había tenido comunicación con éste antes de su batida. ${ }^{32}$ Por último, desconcierta la aparente facilidad con que los homicidas desistieron de su intención de arrojar el cuerpo del guardia al río y se resignaron a huir después de escuchar las razones en contrario de Benito Soriano y sus acompañantes.

En suma, si se analiza la actuación del gobernador del valle desde la óptica paternalista mencionada en el preámbulo de este trabajo, la pauta seguida trae a la memoria las instrucciones para secretarios de estados señoriales que Gabriel Pérez del Barrio Angulo había publicado un siglo antes y que, en caso de conflicto con los vasallos ( $\mathrm{y}$ éste de Cofrentes también lo era), prescribían, en primer lugar, recabar buena información para, a renglón seguido, ajustar acuerdos «paternales» con los miembros del concejo y prender a los revoltosos para escarmiento del resto de la comunidad. ${ }^{33}$ Mutatis mutandis, y con la salvedad de que, a falta de presos, hubo de contentarse con el embargo de los bienes de los reos, Luis Clavijo parece haber obedecido a esta misma estrategia, orientada a proteger y minimizar los daños a la villa, incluidas las posibles responsabilidades penales de las autoridades locales, sobre las que, no se olvide, recaía la obligación de prevenir el fraude contra la renta de salinas.

32. Como así había sido. En concreto, el 4 de febrero Ginés se había presentado en la casa del gobernador en Zarra para que éste diera cumplimiento al contenido de su despacho de guardia de la renta de salinas. (Ibidem, $10 \mathrm{v}$ ).

33. I. ATIENZA HERNÁNDEZ, «Consenso, solidaridad vertical e integración...», p. 309. 


\section{2.-LLEGA EL VISITADOR}

Francisco Driget, marqués de Malespina, intendente de Ios reinos de Valencia y Murcia, escribió al gobernador Clavijo el 2 de marzo acusando recibo de su carta de 27 de febrero. Cinco días más tarde, a instancia de Juan de Belagarde, administrador general de la renta de salinas, y habiendo consultado con Sebastián del Castillo, alcalde de la Sala del Crimen de la Audiencia y su asesor en la ciudad de Valencia, ordenó a Francisco Pardo de la Casta, visitador de dicha renta, que pasase a la villa de Cofrentes y a las poblaciones que fuese menester para la averiguación de la muerte del guardia Ginés García y la captura de sus agresores y cómplices, autorizándolo a requerir a los jueces, alcaldes y justicias de las mismas todos los autos y cédulas concernientes al delito, así como el auxilio, gente de armas y cárceles que pudiera necesitar. ${ }^{34}$

El juez Pardo de la Casta tenía amplia experiencia en la represión de los fraudes contra la Real Hacienda, no en vano llevaba investigados más de una veintena de casos en los últimos años. ${ }^{35}$ Una vez instalado en Cofrentes, hizo comparecer en primer lugar a los testigos presenciales de los hechos: Cristóbal García, Benito Soriano y Bernabé de Aba. En lo esencial, sus nuevas declaraciones, bastante más prolijas que las prestadas ante Clavijo, ratifican lo contenido en aquéllas. Sin embargo, hay en éstas pormenores que demuestran que los sucesos acaecidos el 21 de febrero no fueron tan fortuitos como los autos del gobernador parecían dar a entender. Para empezar, no fue por azar que, en ausencia de Pedro Pardo, alcalde de la aldea de Casas del Río, al que había ido a buscar primero, Ginés se hiciese acompañar por García y Soriano, ya que ambos «lo conocían muy bien de algunos años a esta parte». Después de enseñarles el título que acreditaba su nombramiento como guardia de la renta de salinas (y que ninguno pudo leer, pues eran analfabetos), les explicó que había llegado a sus oídos que en el barranco del Martinete se «estaba fabricando crecida porción de sal» y que necesitaba su auxilio para hacer aprehensión del fraude. Que Soriano fuese a recoger su escopeta -dato que contradice el testimonio de Cristóbal García ante el gobernador, conforme al cual «sólo llevaba armas Ginés García»- es señal de que era sabedor de las dificultades con que se podían enfrentar. Antes de abandonar la aldea, de camino al barranco, el guardia pasó a registrar las casas de Asensio y Pascual Serrano y de Bernabé de Aba, lo que evidencia su voluntad de proceder concienzudamente.

Los fabricantes de sal estaban en lo cierto cuando pensaron que la intención del guardia no era detenerlos, para lo cual carecía de medios suficientes, sino incautarse del cuerpo del delito. Así se lo confesó Ginés a sus acompañantes al divisar desde lo alto del barranco a los defraudadores. Por ello provocó su espantada disparando al aire un escopetazo y por eso mismo no tuvo inconveniente en que recuperasen sus atos con comida. Pero en modo alguno estaba dispuesto a tolerar que se perdiesen las pruebas

\footnotetext{
34. Ramo $2^{\circ}, 1$ v-4 r y 15 r- $19 \mathrm{r}$.

35. Sólo entre 1743 y 1746 había sido comisionado por la intendencia para investigar fraudes en Alicante, Callosa d'En Sarrià, Elda, Gandia, el Verger, Salinas, Monóvar, Massamagrell, Manises, Bétera, Jávea, Massarrojos, Teulada, el Grao de Valencia, Villajoyosa, Orihuela, Vallanca, Dos Aguas y Ademuz.
} 
del fraude: sartenes, hornillas, sal fabricada, etc... (en cuya descripción, cabe imaginar que a petición del visitador, se detienen los declarantes con mayor detalle que en sus primeras atestaciones). De ahí que el guardia apuntase con su trabuco a los salineros cuando éstos se arrojaron sobre sus utensilios y que no dudase en abrir fuego contra Correcher, pese a que también era, como luego descubriría Pardo de la Casta, conocido suyo.

Por último, y como era de suponer, tanto la pugna del guardia con los fabricantes de sal como el posterior encuentro de los testigos con los que le acababan de dar muerte fueron en realidad más virulentos de lo que reflejaban los autos de Clavijo. Cristóbal García confiesa que temió lo peor cuando Ginés y él echaron a correr, pues sus perseguidores «decían con voces altas que qué se diría de ellos quedando su compañero muerto y que aquellos perros se salieran con vida». Benito Soriano añade que «Juan Gómez llevaba untadas las manos de sangre y Juan Alarcón -el Grillo- tenía en la mano una rasera de hierro de media vara de largo». Por su parte, Bernabé de Aba agrega que, ocultos tras un lentisco, los matadores de Ginés intentaron tender una emboscada a Soriano. A buen seguro, la escopeta que éste portaba y la del guardia, que Cristóbal García había rescatado en la trifulca y llevaba al hombro, les ayudaron finalmente a disuadir a los homicidas de deshacerse del cadáver de Ginés. ${ }^{36}$

En cualquier caso, más allá de desmentir la versión de los hechos que evocan los autos iniciales, el propósito fundamental del juez de comisión era desvelar la verdadera dimensión de la trama delictiva, a fin de desarticularla por completo. Las primeras pistas en esa dirección le fueron dadas por Vicente Correcher, uno de los hombres que había custodiado los restos mortales de Ginés García y Cristóbal Correcher la noche del 21 de febrero (y que, igual que los demás, no había aportado nada al respecto en su declaración ante el gobernador). Al ser preguntado por el tiempo que la fábrica de sal llevaba en funcionamiento y los individuos que participaban en ella, contesta:

«que sabe por cosa notoria que, de un año a esta parte, se ha fabricado sal en dicho barranco por las personas que deja declaradas y otras, tan públicamente que no han tenido otro modo de vivir y sólo se han ejercitado en este género de trabajo, y particularmente desde el día y fiesta de Todos Santos del año pasado, que no ha cesado la fábrica de dicha sal. Y que los conductores para su despacho a lo interior de este reino han sido Antonio Landete con dos machos, y su cuñado Miguel Navarro de Vicente con uno; Julián Delgado con dos burros; Pedro Navarro, hijo de Nicolás Calavera, con otros dos; y Francisco Delgado, todos de esta villa, con otros, a los cuales ha visto públicamente sacar y llevar dicha sal. Y dos o tres días antes de cuando sucedieron dichas muertes, sacaron cinco cargas el dicho Antón Landete en sus dos machos, Miguel Navarro en el suyo y Julián Delgado en sus dos borricos, y aunque no sabe adónde, le parece que para la Ribera, porque estando el testigo trabajando en la puente de esta villa como seis u ocho días después los vio venir de hacia aquella parte con cargas al parecer de panizo»». ${ }^{37}$

36. Ramo 2", 20v-36r.

37. Ibidem, $39 \mathrm{r}-\mathrm{v}$. 
Quiso averiguar entonces Pardo de la Casta si, siendo tan notorio el fraude, las autoridades de Cofrentes habían practicado alguna diligencia para estorbarlo, a lo que el testigo respondió que sólo le constaba que el anterior alcalde, Francisco Pardo, y su regidor mayor habían pasado una vez por aquel sitio para impedir la fabricación de sal. Como corolario, Cristóbal Martínez, interrogado a continuación por el juez, adujo que la desgracia y el desorden acaecidos se habrían podido evitar «si las justicias hubieran estado vigilantes $\gg .{ }^{38}$ Con estas primeras denuncias de negligencia el asunto empezaba, pues, a tomar una peligrosa deriva hacia el conflicto jurisdiccional, de consecuencias imprevisibles.

Para complicar más las cosas, el 12 de marzo, un día después que el visitador hiciera su entrada en la villa, retornó a la misma el gobernador Clavijo para proseguir su investigación, en paralelo y con independencia de las actuaciones del juez real. Enterado por María Barberán, mujer de uno de los fugitivos, Cristóbal Villena, de que Miguel García, llamado «de la Matilde», labrador de 65 años y dueño de diversas parcelas de tierra en el término del municipio, había ido al barranco del Martinete en pos de su hijo Nicolás el día de autos, mandó prender a padre e hijo y embargar sus bienes. Esta vez tuvieron más suerte los alguaciles, ya que al menos pudieron arrestar al primero de ellos. Fue necesario interrogarlo por dos veces y tomar entre medias declaración a otros cinco testigos para que al fin confesase, el 21 de marzo, lo que Clavijo sabía ya por medio de la esposa de Villena, esto es: que su hijo Nicolás también participaba en la fábrica de sal; que se había encontrado en el camino con Ginés García, al que en balde había intentado persuadir de que se llevase un poco de sal y unas cuantas sartenes y dejase lo demás a los salineros; y que había terminado presenciando la riña del guardia con los defraudadores, la muerte de Correcher y la frustrada fuga de Ginés, todo lo cual el reo afirma haber callado por miedo a las represalias de sus agresores. ${ }^{39}$

Al día siguiente, el 22 de marzo, el gobernador ordenó al pregonero de Cofrentes que fijase en los puestos públicos un edicto por el que emplazaba a los once culpados huidos: Francisco Alarcón, Juan Alarcón, Francisco Ródenas, los hermanos Juan y José Gómez, Diego García, José de Sotos, Cristóbal Villena, Melchor López, Esteban Cañas y Nicolás García, a comparecer ante su audiencia o presentarse en la cárcel de la villa en el plazo de nueve días, pasados los cuales serían juzgados en rebeldía hasta la sentencia definitiva. ${ }^{40}$ Ésta sería su última tentativa de limitar los efectos de la sanción penal a un número moderado de vecinos de la población. Y, en la práctica, también su postrer ejercicio de autoridad en Cofrentes.

Curiosamente, mientras esto sucedía en la villa, el juez Pardo de la Casta perdía el tiempo buscando en vano a algunos de los reos en las aldeas castellanas de Casas de Ves y Alcalá del Río, donde, según «noticia secreta» que se le había dado, se hallaban escondidos. Después de seis días continuos de rastreo, el juez sólo pudo constatar que una semana antes habían transitado por dichos lugares, sin detenerse en ellos. De vuel-

\footnotetext{
38. Ibidem, $42 \mathrm{r}$.

39. Ramo $3^{\circ}, 72 v-74 \mathrm{r}$.

40. Ibidem, 76 v $77 \mathrm{r}$.
} 
ta a Cofrentes, su frustración debió transformarse en enojo al tener conocimiento del edicto publicado por Clavijo en su ausencia. Y aún hubo de ser mayor su enfado luego de registrar las fuentes salobres del Martinete el 26 de marzo y comprobar por sí mismo los daños que, por orden del gobernador, se habían hecho en la fábrica de sal al término del levantamiento de cadáveres. Ésta es su minuciosa descripción del paraje:

«Se encuentra haber en él dos fuentes de agua salada de buen gusto y calidad: la una debajo de una peña grande, con cinco palmos de agua, bastante ancha, y otra de tres palmos a la parte de abajo, de la propia calidad, y alrededor de éstas nueve hornillas deshechas y derribadas, las mismas que se hallaban, según expresaron dicho Soriano y Cristóbal, con sus sartenes y fuego fabricando sal. Y próximas a éstas cuatro pozos, al parecer hechos para escurrir y enjugar la sal que en aquéllas se fabricaba, poniéndola sobre unas losas grandes que manifestaban, según la sal que éstas tenían pegada, habían servido para mantenerla apilada mientras se enjugaba y escurría su humedad. Y más arriba de este sitio y en el mismo barranco, como unos cuarenta pasos, se encuentran otras cinco hornillas también demolidas, tres pozos para el propio efecto y, como unos veinte pasos al barranco abajo, otras dos fuentes muy pequeñas, también salobres, con alguna sal cuajada alrededor de éstas. Y medido el rancho y aparato que estaba establecido para el fin de dicha fábrica contiguo a las mismas fuentes es 19 pasos de largo y 17 de ancho, con muchas prevenciones hecho, así para hacer la comida y tener el ato, como para el reposo de las caballerías que a este sitio traían, según lo demuestra la paja y estiércol, entrada y salidas a este barranco de camino muy espacioso y triado, azagadores y escurridores por donde conducían la leña y atocha para el fuego y adorno de dicha fábrica, como lo manifiesta crecida porción de leña que se ha encontrado en este sitio, al parecer de prevención para la fábrica de dicha sal, sin otras muchas latas y palos largos que dan a entender han servido para bardales y chozas para el abrigo y resguardo de dicha fábrica, según en mi presencia lo asegura dicho teniente, Cristóbal y Soriano, pues no se halla subsistente y en forma, por haber mandado se diese fuego a todo el gobernador de esta villa a tiempo que se recogieron los cadáveres que quedan dichos». ${ }^{41}$

La destrucción de pruebas ordenada por Clavijo agotó la paciencia del juez de comisión. Al regresar del barranco mandó al gobernador que se inhibiera de la causa y entregase a su escribano los autos formados, «habida cuenta que el conocimiento del delito toca privativamente al señor corregidor y justicia mayor de la ciudad de Valencia, juez único y privativo de las reales rentas del reino y superintendente general de la de salinas». Mas la respuesta de Clavijo no fue la esperada. En vez de plegarse dócilmente al requerimiento del visitador, contestó que la causa que se sustanciaba no era sólo sobre la muerte del ministro de la renta de salinas, sino también sobre la de Cristóbal Correcher, vecino de Cofrentes, hallados ambos en el barranco del Martinete, propio de su jurisdicción, y que tenía orden del fiscal de la Audiencia de continuar la averiguación del delito hasta su determinación, de manera que no podía asentir a su exhorto. El conflicto de competencia estaba servido. Leídas la respuesta de Clavijo y la

41. Ramo $2^{\circ}, 49 \mathrm{r}-\mathrm{v}$. 
carta del fiscal, Pardo de la Casta optó por suspender diligencias hasta que el marqués de Malespina lograse la inhibición del gobernador. ${ }^{42}$

Dos meses exactos tardaron los miembros de la Sala del Crimen de la Audiencia en atender la súplica del intendente de que se proveyese el sobreseimiento de Clavijo en la causa y la acumulación de sus autos a los que Pardo tenía hechos. ${ }^{43}$ Dos meses durante los cuales ambos pesquisidores se restituyeron a sus respectivos domicilios. Dos meses en los que los habitantes de Cofrentes volvieron a la rutina cotidiana, ignorantes de lo que estaba por venir.

\section{3-VUELVE EL VISITADOR, SE DESATA LA TORMENTA}

Libre al fin de las interferencias del gobernador del valle, Francisco Pardo de la Casta retornó a Cofrentes el 12 de junio, llevando consigo al escribano Pedro León Vidal, al teniente de la renta de salinas José Guinda y a los guardias Francisco Vicente y Andrés Bonilla. ${ }^{44}$ Tal y como había temido su antagonista, las declaraciones que presto tomaría a nuevos testigos iban a dar un brusco giro a la investigación.

Bien fuera por dolor, bien por venganza, o por la suma de ambos sentimientos, la comparecencia de Nicolás Correcher, hermano del difunto Cristóbal, ante el visitador destapó la caja de los truenos. No era éste un testigo cualquiera, ya que a la información que de primera mano hubiera podido obtener del finado acerca del contrabando de sal sumaba la que poseía como arrendatario de la tienda de la villa, eje del comercio local ${ }^{45} \mathrm{Al}$ margen de nuevos detalles sobre la muerte de su hermano, que conocía por la versión del lance que le había dado uno de los reos fugitivos, Diego García (y que, entre otras cosas, acredita la relación -ya mencionada- de Cristóbal con Ginés), el testimonio de Nicolás Correcher puede considerarse crucial por varias razones. Ante todo porque, además de los ya culpados, incrimina a un gran número de vecinos de la villa de Cofrentes y de la aldea de Casas del Río en la fabricación, distribución y venta de la sal, no sólo en el barranco del Martinete, como hasta entonces había creído la justicia, sino también en el de Tenesla, muy próximo a éste, desvelando la naturaleza colectiva -casi comunitaria- del fraude contra la Real Hacienda. En segundo lugar, porque muestra que los defraudadores estaban prevenidos de la inminente llegada del guardia de la renta de salinas, lo que explicaría la menor concurrencia de fabricantes el día de autos. Y por último, porque ofrece datos aproximados sobre el volumen de producción y los precios de venta de la sal.

Con relación a las fábricas, participantes habituales en ellas y tiempo que éstas llevaban en funcionamiento, el declarante asevera que:

42. Ibidem, $52 \mathrm{r}-56 \mathrm{v}$.

43. Ramo $3^{\circ}, 87 \mathrm{r}-\mathrm{v}$.

44. Ramo 4", $13 \mathrm{r}$.

45. Había obtenido la cesión en arriendo en noviembre de 1743, precediendo subasta del propio gobernador Clavijo, por tiempo de cuatro años y precio de 125 libras anuales. (ARV, Protocolos de Juan Teruel, $3471,145 \mathrm{v}-147 \mathrm{r}$ ). 
«cuando sucedieron las dichas muertes no sabe hubiese otros en el referido barranco fabricando sal más que los que tiene dichos, pero bien sabe que en el día de antes, 20 del mismo, se hallaban también fabricando sal, juntamente con los antedichos, Joseph Arocas, hijo de Juan, de mal nombre Moreno, Julián Delgado, hijo de Joseph, Francisco Delgado, hijo de Joseph, y que éstos se vinieron a esta villa dicho día 20 por la tarde, por haber tenido noticia que dicho Ginés García, guarda, había de ir a dar vuelta a dicho barranco, y aun dicho Julián Delgado lo ejecutó en la misma mañana del día 21 y antes que el referido Ginés llegase al referido barranco, que se hallaba en él con caballerías para cargar sal. Y también sabe que, a más de los que deja dichos, se han empleado en el mismo ejercicio y fábrica, así en el dicho barranco del Martinete, como en el de Tenesla, que está próximo a las Casas del Río de esta jurisidicción, Andrés Landete, Llamado el Ayorín, Diego Pardo, Joseph Grau, Vicente Arocas, hijo de Vicente, Joseph Alarcón, de mal nombre el Grillo, Joseph Arocas, hijo del Fraile por mal nombre, Pedro García, mozo, hijo de Pedro, Pedro Navarro, hijo de Nicolás, llamado Calavera, todos vecinos de esta villa, y Cristóbal García y Cristóbal Pardo, hijo de Juan, de mal nombre Campana, habitadores de las Casas del Río de esta jurisdicción, y Juan Ximénez, también vecino de ésta, y así éste como todos los demás que deja declarados la han hecho y fabricado de año y medio a esta parte, y especialmente del día de Todos Santos pasado próximo hasta el día 21 de febrero de este año en que sucedieron las referidas muertes, que estuvo corriente la susodicha fábrica, así en el nominado barranco del Martinete como en el de Tenesla, a ocasión de que se repartían las aguas de dicho barranco y luego que tas apuraban de uno se pasaban al otro, o se repartían unos en una parte y otros en otra. Y sólo dejaban estas fábricas cuando llovía o tenian otras precisas haciendas en que ocuparse, cuyos excesos y delitos han sido públicos en esta villa y el testigo los ha encontrado muchas veces que iban y venian a las referidas fábricas, y comunicado con ellos sobre este asunto, pues continuamente se estaban cruzando de un puesto a otro las cargas de sal. Y también lo sabe por habérselo dicho muchas veces su hermano, Cristóbal Correcher, difunto, que se ejercitaba en lo mismo». ${ }^{46}$

No menos circunstanciada es su relación de distribuidores y vendedores, que eleva a una treintena de individuos:

«Los sujetos y conductores de dichas sales fabricadas han sido Julián García, casado, con dos burros, Antón Landete con dos machos, Pedro Grau, de estado casado, con tres burros, Alonso García con dos machos, Miguel Navarro de Vicente con un macho; Pedro García de Alonso con dos machos, Joseph Alonso, hijo de Juan, con dos burros, Joseph Gómez, llamado el Curica, con dos machos, Diego Poveda con un macho, Cristóbal Pardo, hijo de Cristóbal, con dos burros, Matias Navarro, el Macareno, con dos burros, Pedro Piula con un macho, Cristóbal y Joseph Gómez, el uno mozo y el otro casado, hijo del Curro por mal nombre, con dos machos, Pedro Navarro, hijo de Nicolás, llamado Calavera, con un burro, Sebastián García con una mula, Joseph García y Muñoz, llamado el Bollo, con un macho, Vicente Muñoz con un caballo, Joseph Muñoz con un macho, Nicolás Muñoz con dos machos, Francisco Delgado, hijo de Joseph, con dos burros, Antonio Muñoz con un macho, Miguel Landete con dos mulas, Juan Navarro con dos burros, Juan Gómez mayor con un macho, Francisco García, hijo de Ponce, mozo, con dos machos, Miguel Montero, que no hace memoria con qué caballerias, Antonio Landete con dos machos, Julián Delgado con dos burros, Miguel Navarro con un macho. Y estos tres últimos sabe que después de sucedidas dichas muertes vinieron de lo interior de este reino, aunque no

46. Ramo 4, 15 v-16r. 
sabe positivamente de qué paraje, de vender cinco cargas de sal. Y no hace memoria si salieron con ella de esta villa dos o tres días antes de que sucedieran dichas muertes o dos o tres días después, bien que fue por aquella razón, y recuerda que se restituyeron a ésta al cabo de siete u ocho días después, a tiempo que el testigo estaba trabajando con otros muchos vecinos de esta villa en la puente del río Cabriel de la misma, con motivo de haberse hundido, entre los cuales se divulgó que venían de vender sal y que, a su parecer, traían de retomo cargas de panizo». ${ }^{47}$

Respecto a las cifras de producción, Nicolás Correcher afirma haber oído contar a los fabricantes que con cada sartén se hacía muy cerca de tres barchillas diarias de sal. Además, añade que al acompañar al gobernador y su comitiva el 22 de febrero pudo comprobar que en el barranco del Martinete había entre 38 y 40 hornillas, y que tenía entendido que, después de las muertes, los reos habían ido a recoger una veintena de sartenes - las mejores- que tenían ocultas en aquel paraje, de lo que se desprende que el número de piezas utilizadas doblaba probablemente el de las incautadas aquel día. Por consiguiente, a título orientativo, cabe estimar que la producción de sal bien podía rondar los 9 cahíces diarios. ${ }^{48} \mathrm{El}$ aumento indiscriminado de la oferta explicaría, por otro lado, el descenso acelerado en el precio de la sal extraída, pues, según manifiesta el testigo, de pagar al principio los traficantes un real de plata por barchilla, que era el precio acordado con los fabricantes, pasaron luego a comprarla a real la barchilla:

«los arrieros y conductores de sal que deja dicho compraban la sal a los fabricantes que tiene declarado a razón de a real de plata la barchilla, que es el precio que entre ellos se tenían puesto, y esto sucedía al principio de mover la fábrica, pero a la otra a lo último ya la daban a real la barchilla, por ser mucho el numero de los fabricantes; y si sucedia no tener éstos bastantes porciones de sal para hacer cargas, se aplicaban a fabricarla también algunos de los dichos conductores». ${ }^{49}$

En definitiva, de ser ciertos los datos que proporciona, en el momento en que fueron desarticuladas, las fábricas de sal del Martinete y Tenesla debían estar generando un capital cercano a los 100 reales de vellón diarios (entre 6 y 7 libras valencianas), sin incluir los posteriores beneficios de comercialización. La suma no es, en absoluto, baladí. Habría bastado con que los fabricantes se emplearan en ellas la mitad del año para que el importe de sus ventas triplicara casi el valor de la renta de 440 libras anuales asignada a perpetuidad a la casa ducal de Gandía en compensación por la incorporación al real patrimonio de su salina de Cofrentes. Es más, si, como aseguran

47. Hidem, $16 \mathrm{v}-17 \mathrm{r}$.

48. La cifra no parece exagerada. Preguntado por la sal que encontraron en el barranco el día del registro, el testigo contesta que «cuatro cahices, con poca diferencia». Si se toma en consideración que el número de fabricantes era menor que de costumbre y que apenas llevaban media jornada trabajada cuando se presentó Ginés García, parece factible que, a pleno rendimiento, se alcanzaran los 9 cahíces diarios. De hecho, incluso podría haber sido superior. Así se infiere de una confesión posterior de Miguel García, quien afirma que uen el barranco del Martinete hay agua para 25 sartenes corrientes y que de 24 a 24 horas se fabrica con cada una tres barchillas de sal... y en el de Tenesla hay agua para poco menoss. En ese caso, la producción de ambas fábricas podría haber llegado a los 12 cahíces al día. (Ibidem, 59 r).

49. Ramo 4', $17 \mathrm{v}$. 
Correcher y otros testigos, los fabricantes sólo soltaban sus sartenes «cuando llovía o tenían precisas haciendas en que ocuparse», el precio de la sal manufacturada podría haber superado las 1.500 libras anuales en que se cifraron las rentas señoriales de Cofrentes entre 1739 y $1749 .{ }^{50}$

La delación de Nicolás Correcher trajo como primera consecuencia el arresto e incomunicación de Cristóbal García, acusado de ser cómplice en la fabricación de sal y de haber negado el auxilio al guardia cuando fue atacado. ${ }^{51}$ Su complicidad en el fraude sería inesperadamente ratificada por un labrador de la villa, Diego García (distinto del reo homónimo) que, al explicar al juez de qué forma habían averiguado los salineros que Ginés estaba a punto de inspeccionar el barranco, señala:

«ha oído decir a Mariana Navarro, mujer de Joseph de Sotos, y Juana Navarro, mujer de Juan Gómez mayor, que Francisco Ximénez, vecino de esta villa, el día 20 de febrero antecedente, les había dicho cómo viniendo de Castilla había encontrado a dicho Ginés García y le había manifestado que aquella tarde se iba a dar vuelta al barranco de Tenesla y al día siguiente por la mañana había de ir a lo mismo al barranco del Martinete, y que, cuidadosas, habían solicitado a Cristóbal García, morador en las Casas del Río, fuese a dar éste aviso a sus maridos y demás fabricantes para que se retiraran, ofreciéndole una peseta y unas esparterías porque dijo estaba descalzo y que se fue con hacerlo y no lo hizo ${ }^{52}$

De ahí la resistencia inicial de Cristóbal García a acompañar al guardia y su posterior pasividad durante la pelea con los fabricantes. Mas no es la única sorpresa que Diego García le tenía reservada al juez de comisión. Preguntado por el tiempo que las fábricas de sal del Martinete y Tenesla llevaban en marcha, el testigo contesta que, si bien era notorio su funcionamiento desde hacía año y medio, algunos defraudadores venían ocupándose en ellas de tres a cuatro años, dato que permitiría fechar el origen del contrabando -en pequeña escala, por supuesto- en 1743, coincidiendo con el inicio del descenso de la producción en el salero de Manuel. No para aquí la cosa. En relación con los canales de distribución de la sal y principales compradores de la misma revela que:

«el despacho y conducción ha sido a Castilla y, lo más común, a lo interior de este reino, pues ha oído decir a Antonio Landete, Alonso García, Miguel Navarro de Vicente, Julián Delgado y Pedro Grau cómo habían llevado al convento de Valldigna cincuenta cahíces de sal fabricada en dichos barrancos; y también ha entendido han conducido otras muchas porciones a los conventos extramuros de la ciudad de Valencia y Xàtiva, como son San Sebastián, San Miguel de los Reyes, el Socorro, San Felipe Neri, la Zaydía de monjas y capuchinos de Xàtiva, y a otros que no hace memoria de sus cercanías». ${ }^{53}$

50. Los derechos dominicales del valle de Cofrentes y sus cinco villas se arrendaron en conjunto durante el período 1740-1743, por lo que no es posible desglosar el valor particular de cada una de ellas. En 1739 los derechos señoriales de la villa de Cofrentes, administrados por un colector, ascendieron a 1.457 libras. En 1749, de nuevo bajo gestión directa, su importe fue de 1.537 libras. (AHN, Nobleza, Osuna, Leg. 988,7 y 8 ).

51. Ramo 4", $20 \mathrm{r}-22 \mathrm{v}$.

52. Ibidem, $24 \mathrm{v}$.

53. Ibidem, $25 \mathrm{v}$. 
Con el clero acababa de topar el visitador, que tendría oportunidad de corroborar la veracidad de esta imputación por doble vía. Primero mediante la declaración de otro testigo, José García, que, además de aportar nuevos nombres a la ya larga lista de defraudadores, intimó que la sal se vendía a los conventos de la Valldigna, capuchinos de Xàtiva, San Bernardo de Alzira, San Miguel de los Reyes y otros extramuros de Valencia, a razón de 6 o 7 sueldos por barchilla. ${ }^{54} \mathrm{Y}$ luego por la confesión del preso Miguel García, que, después de cuatro meses de cárcel, acabaría derrumbándose y dando información detallada sobre las rutas del tráfico, competencia entre vendedores y precios pagados por los religiosos:

«la llevaban a vender a los conventos de lo interior del reino, como son: al de Luchente, la Valldigna, los de San Felipe, Carcagente, los de extramuros de Valencia, San Felipe, San Sebastián, el Socorro, la Zaydía, San Miguel de los Reyes, los de Murviedro y Segorbe. En esta forma: al de Valldigna llevaron Pedro García de Alonso, su hijo Alonso y Juan García de Sebastián, en dos viajes, 25 cahíces; a los de San Felipe llevaron Antonio Landete, Nicolás Muñoz y Alonso García un viaje de 6 cahíces y medio, y éstos mismo con Pedro Fernández, Piula, llevaron al de Luchente otro viaje de 6 cahíces; al de Carcagente llevaron los dichos Pedro y Alonso García, padre e hijo, otro viaje de 4 cachíces; al de Alaquás llevó dicho Nicolás Muñoz y Antonio Landete otro viaje de 5 cahíces; y al convento de Alzira otra porción que no se acuerda de cuánta, y aunque los demás comprendidos en esta declaración han llevado muchísimas otras porciones, y aun los mismos antecedentes a los mismos conventos y otros, no lo tiene en memoria. Y muchas veces ocultaban estas ventas por que no fuesen otros y se aparroquiasen en estas distribuciones. Y nunca le han manifestado que vendiesen en otra parte, si sólo a los conventos, a precio cada barchilla de siete, ocho sueldos, $y$ otras a seis, y en el de la Valldigna les daban una barchilla de panizo y un real por una de sal, de forma que el que llevaba dos cargas de macho le dejaba de beneficio en cuatro o seis días... de ocho a diez pesos).$^{55}$

En el precio final que el clero abonaba por la mercancía radica una de las claves del fraude. Incluso en el mejor de los casos para los traficantes (esto es, que les pagasen 8 sueldos por barchilla), el precio resultante era muy inferior al oficial, en aquellos años encarecido -como se ha dicho-por un suplemento extraordinario de 13 reales por fanega, lo que explica de sobra el interés de los conventos por adquirir el producto a bajo coste. $^{56}$ Por lo que concierne a los márgenes de beneficio que obtenían los conductores y expendedores, es evidente que eran amplísimos, por cuanto los precios de venta llegaban a multiplicar por seis el de compra. En resumen, y aunque sea imposible determinar el volumen de negocio movido por las salinas clandestinas de Cofrentes, cabe aventurar, tomando como referencia los valores «medios» de extracción y comercialización con-

54. Ibidem, $28 \mathbf{r}$.

55. Ibidem, $59 \mathrm{v}$.

56. Obsérvese que el monto del suplemento (equivalente a 78 reales por cahíz) excedía por sí mismo del mayor precio que los conventos pagaban a los traficantes de Cofrentes: 72 reales por cahíz. Por otro lado, cabe recordar que la iglesia valenciana ya había tratado de eludir en 1713 el pago de los impuestos fijados por la monarquía sobre el precio de la sal, conflicto que desembocó cuatro años más tarde en la expulsión del vicario general Jacinto Ortí, al que se consideró artífice de una estrategia premeditada de oposición a la intendencia. Cfr. R. FRANCH BENAVENT, «El cambio de naturaleza de las rentas...», pp. 272-281. 
signados en los autos (capacidad de producción diaria, número de jornadas trabajadas, precios de venta, etc.) que el importe global de las ventas pudo oscilar entre 6.000 y 7.000 libras al año, cantidad esta última próxima al precio en que se arrendaron los derechos dominicales del valle de Cofrentes y sus cinco villas entre 1740 y $1743 . .^{57}$

El asunto se enredaba sobremanera. La muerte de Ginés García había sacado a la luz la existencia, no ya de un centro de fabricación de sal ilícito, sino de una red bien organizada de distribución y venta de la que formaban parte más de 60 vecinos, que tenía como destinatarios principales a los conventos de las comarcas centrales del reino, generaba un capital varias veces superior al valor de la renta señorial de la villa y, por ende, lesionaba muy gravemente los derechos de la Real Hacienda. Por añadidura, había indicios de que todo ello se había hecho con la connivencia de las autoridades locales. Ante la dimensión que el fraude cobraba ante sus ojos, atrapado entre su deseo de llegar hasta el fondo del problema y la falta de medios para conseguirlo, Pardo de la Casta escribió al intendente Malespina el 22 de junio para consultarle los pasos que debía dar, en lo que constituye un explícito reconocimiento de los límites de la capacidad punitiva de la justicia real:

«considerando la difícultad que tendrá la prisión de esta multitud y los inconvenientes que pueden resultar, siendo quasi la mitad de los vecinos de este pueblo, no sólo por hallarse muchos prófugos y prevenidos de armas en los montes, sino por el enlace de parentesco y amistad que los reos tienen con los que no lo son, que constituye dificultoso, si no imposible, el adelantamiento de la sumaria y justificación; deseando su merced el acierto y administrar justicia en cumplimiento de su encargo, sin causar turbación, tumulto ni los otros inconvenientes que se pueden temer de opresión tan notable quasi a todo un pueblo, no siendo bastantes a contenerla los cinco dependientes que se hallan de esta renta... $\rangle^{5 \mathrm{~K}}$

Por si ello fuera poco, las sospechas de negligencia u omisión que recaían sobre la justicia local se hicieron extensivas de súbito al mismísimo gobernador del valle. En efecto, al comparecer ante el visitador, Asensio Serrano, alguacil del monte, puso en su conocimiento que, con ocasión de haber hallado tres sartenes con sal cuajada en el barranco de Tenesla, en abril de 1746, fue a dar parte a Clavijo, quien le respondió «que se cuidase de su monte y no se metiera si hacían sal o no, que esa incumbencia no le tocaba a él ni a dicho gobernador, pues era encargo que sólo debia entender el alcalde». Menos verosímil resulta la imputación de otro testigo, Andrés Ponce, según la cual los salineros se atrevían a fabricar tan públicamente la sal porque «el gobernador de la villa les tenía mandado la hiciesen, pero que no se le pusiesen delante, y que les tenía mandado a sus alguaciles no les embarazasen este ejercicio... si no es en el caso que fuesen forasteros y viviesen en otra jurisdicción». ${ }^{59}$ Es muy difícil saber cuánto de

57. AHN, Nobleza, Osuna, Leg. 1015, $8^{7}$. En el arriendo, por precio de 7.500 libras anuales, no se incluian las 440 libras de renta perpetua por la salina incorporada al real patrimonio, ni los quindenios, ni los emolumentos de la jurisdicción civil y criminal.

58. La carta lleva fecha de 22 de junio, pero, extrañamente, no se despachó al marqués hasta cuatro días más tarde. (Ramo $4^{\circ}$, Ibidem, $29 \mathrm{v}$ ).

59. Ibidem, $39 \mathrm{r}-45 \mathrm{v}$. 
cierto hay en tales denuncias. De serlo, habría que concluir que Luis Clavijo trató de fomentar el desarrollo mercantil y la riqueza de los estados bajo su administración a despecho del monopolio regio sobre la sal y de sus obligaciones más elementales con la duquesa de Gandía, relajando el control coactivo en beneficio del aumento de las rentas de sus vasallos. Pero esto no parece creíble. Por el contrario, siendo notoria la disputa que Pardo había mantenido con Clavijo, estos testigos pudieron querer regalar los oídos del juez y ganarse su confianza poniendo en entredicho la honestidad de su rival, o bien, simplemente, resarcirse de antiguas cuitas con el gobernador. El hecho de que algunas de sus acusaciones fueran desmentidas por otros vecinos así lo sugiere. ${ }^{60}$

Mientras tanto, y a la espera de la respuesta de Malespina, el visitador optó por redoblar las cautelas. Buen ejemplo es su auto de prisión contra Nicolás Navarro, alias Calavera, y su hijo Pedro, cómplices en la conducción y venta de sal, en el que encomienda a sus alguaciles que disimulen el arresto atribuyéndolo, no a esta causa, sino a la verificación de una multa que se les había impuesto un año antes por fabricar sal en la vieja salina de los duques, con la finalidad de que «no se origine la más leve inquietud y zozobra, y que los demás reos que resultan en estos autos no hagan fuga» ${ }^{61} \mathrm{La}$ conducta de los Calavera - el apodo les iba que ni pintado-es, por cierto, doblemente sintomática del clima de competencia tempranamente surgido entre los defraudadores (en la línea de lo apuntado por el reo Miguel García acerca de la ocultación de clientes), ya que, por una parte, delata su deseo de maximizar los beneficios procurándose por sí mismos el género, al margen del pacto alcanzado entre vendedores y fabricantes, y, por otra, muestra que, en su búsqueda de materia prima, no vacilaron en tomar el atajo que les quedaba más a mano, aun a costa de comprometer seriamente a las autoridades de la villa, a saber: elaborarla con el agua de la salina incorporada al real patrimonio, «que estaba en hacienda propia de dicho Calavera, cerca de la fuente de la Oruga, camino de Requena». ${ }^{62}$ Considerando ambas circunstancias, no parece casual que la de Nicolás Navarro y su hijo fuese la única aprehensión de sal hecha por la justicia de Cofrentes en todo el año 1746, el de máxima actividad extractiva y mercantil.

El juez Pardo recibió las instrucciones reservadas del intendente el 5 de julio. En su contestación, Malespina se lamentaba de la «gravísima ofensa de la regalía» que se había producido y de la virtual aprobación con que las justicias la habían disimulado, y disponía la formación de piezas separadas de autos en virtud del delito imputado a cada reo (homicidio del guardia, fabricación de sal, distribución y venta, encubrimiento), actuando con la mayor prudencia y evitando de momento la prisión y embargo

60. Asensio Serrano afirma que Benito Soriano le había confesado tener orden expresa del gobernador de callar que Cristóbal García y él llevaban armas cuando acompañaron a Ginés al barranco del Martinete, pues el lugar se echaría a perder por haber dejado aquéllos de cumplir con su deber de defender al guardia y a la Real Hacienda. Sin embargo, Soriano niega haberle dicho tal cosa. Ibidem, $37 \vee$ y $47 \mathrm{r}$.

61. Ibidem, $34 \mathrm{v}-35 \mathrm{r}$.

62. Ibidem, $60 \mathrm{r}$. 
de bienes de los culpados -especialmente de quienes se hallasen en el ejercicio de la jurisdicción ordinaria-, hasta que pudiera examinar el procedimiento..$^{63}$

Un extraño suceso vino a probar al punto lo enrarecida que estaba la situación y cuánto convenía extremar las precauciones. De acuerdo con las advertencias que se le habían hecho, Pardo abrió un auto separado para dilucidar la responsabilidad del alcalde de la villa, Pedro Muñoz, en la ocultación del fraude. Días después de interrogarlo y amonestarlo por su tibio comportamiento y nula provisión de medidas de vigilancia, y habiéndose trasladado el juez con su ronda a Casas del Río, tres de los cuatro reos detenidos: Cristóbal García y los Calavera -padre e hijo-, se fugaron de la cárcel del castillo de Cofrentes. No les fue difícil: el alcaide se había ausentado sin dejar guardia a su cargo; bastó que alguien cortase desde fuera una simple barra de madera para que pudieran escapar. Pero la libertad les duró muy poco (al menos a los Calavera). Unas horas más tarde fueron capturados de nuevo en la iglesia parroquial, a tiro de piedra del castillo, donde (quién sabe por qué incomprensible razón) habían ido a refugiarse. ${ }^{64}$ Lo más curioso del caso - y lo que alimenta toda clase de sospechas sobre quién pudo maquinar semejante evasión- es que fue el propio alcalde quien puso al visitador sobre la pista de los fugitivos. In tempore opportuno. Después del lance, Pardo sobreseyó la causa relativa al delito de encubrimiento. De hecho, dio por terminadas todas sus pesquisas. ${ }^{65}$

\section{UN ALCANCE INCIERTO}

A finales de julio, el administrador de la renta de salinas Juan de Belagarde remitió al intendente un cuadro de conclusiones deliberadamente sombrío, encaminado a obtener un castigo ejemplar para los involucrados en el fraude. Por lo que toca a la muerte de Ginés García, desencadenante del proceso, Belagarde creía probado que los fabricantes furtivos se habían ensañado con el guardia después que éste hubiera matado accidentalmente («se le fue un trabuco») a Cristóbal Correcher. Respecto al fraude en sí, afirmaba que la fábrica de sal había tomado cuerpo en los dos últimos años «como si fuese patrimonio propio de los vecinos de Cofrentes», a tal punto que, «siendo los vecinos hasta en número de ciento y cuarenta, resultan defraudadores de la renta más de setenta» y cómplices o interesados en el asunto casi todos los demás, con la abierta tolerancia de las autoridades de la villa. En consecuencia, Belagarde solicitaba el auxilio militar conveniente para atajar el abuso, así como una sanción igualmente severa

\section{Ibidem, $49 \mathrm{x}$.}

64. La documentación es confusa. Aun cuando el alcalde dice haber reintegrado a los tres fugados a la cárcel, sólo los Calavera permanecen en ella en febrero de 1748, desconociéndose el paradero de Cristóbal García. Ramo $7^{\circ}, 12$ v.

65. El auto particular sobre la responsabilidad del alcalde en la ocultación del fraude tiene sólo 5 folios (Ramo $5^{\circ}$ ). La declaración de Pedro Muñoz se tomó el 11 de julio. Tres días después partió el juez Pardo hacia Casas del Río a fin de practicar unas diligencias. Esa misma noche se fugaron los tres presos. Al día siguiente, Pedro Mutioz escribió al visitador para avisarle de que los detenidos se habían escapado «luego que han sabido que dicho don Francisco y la ronda se han ausentado». (Ramo 1, $26 \mathrm{r}$. Ramo $\left.4^{\circ}, 67 \mathrm{r}-\mathrm{v}\right)$. 
para las instituciones religiosas fomentadoras del contrabando. ${ }^{66}$ Visto con sus ojos, el caso de Cofrentes parecería, salvando las distancias, un «presagio» del motín de la localidad cacereña de Ceclavín, en 1755, estudiado por Miguel Ángel Melón Jiménez, donde la abierta connivencia del clero local con los numerosísimos vecinos que habían hecho del contrabando con Portugal su modo de vida hizo necesaria la ocupación militar de la villa. ${ }^{67}$

No era del mismo parecer el presidente del Consejo de Hacienda, el marqués de San Gil, a quien Malespina trasladó la petición del recaudador. En vez de aprobar la exhibición de fuerza y la ejemplaridad, San Gil prescribió una dosis suplementaria de cautela. Para lograr la prisión de los fugitivos y detener a los traficantes dispuso que se alertase a las justicias de las comarcas adyacentes, por cuanto «necesariamente han de encaminarse por los pueblos de aquella circunferencia, donde, puesto el eficaz remedio de la diligencia, ella misma irá conteniendo este pernicioso desorden». A la solicitud de auxilio militar del recaudador replicó exigiendo el aumento del número de guardias de su renta, «porque, si por no tener el dispendio de mayores salarios, los ha de padecer la renta en detrimento de los valores sucesivos, no deberá V.S. permitírselo, antes bien remediar éste o cualesquiera otros abusos que pueda ser nocivo a los intereses de la Real Hacienda». Por lo que atañe al clero, ordenó incoar causa separada contra los conventos, con la finalidad de delimitar responsabilidades (aunque no se conservan pruebas de que se cumpliese tal cosa). Por último, y a la luz de la entidad del fraude, el presidente del Consejo mandó recabar información fidedigna sobre la capacidad de producción de las fábricas del Martinete y Tenesla para saber si «recogido el derrame de aquellas aguas salitrosas, podrá ser dable construcción de proporcionada salina $a$ beneficio de la Real Haciendar ${ }^{68}$

A falta de sentencias, ${ }^{69}$ puede obtenerse un balance aproximado del conjunto de actuaciones judiciales a partir de los pedimentos del abogado fiscal designado para la causa por el intendente Malespina: Pedro Vicente Traver. Entre el 9 de diciembre de 1747 y el 14 de febrero de 1748, Traver solicitó la aprehensión y embargo de bienes de 11 reos acusados de fabricar sal, 26 de fabricarla y venderla, otros 21 de expenderla y 11 fabricantes más implicados en la muerte de Ginés García. (A la postre, no hubo, pese a las indicaciones de Malespina, culpados de encubrimiento). En total, 69 vecinos imputados que, en realidad, resultaron ser 67 , por haberse producido diversos

66. Ramo $1^{\circ}, 27 \mathrm{r}-29 \mathrm{v}$.

67. Las distancias a que me refiero no son sólo espaciales y temporales. El contrabando con Portugal era un factor estructural de la economía de Ceclavín, cosa que no llegó a darse en Cofrentes. Asimismo, es harto dudoso que en la villa valenciana hubiera podido estallar un tumulto armado como el que se produjo en la localidad extremeña con ocasión del registro de los domicilios de los contrabandistas. Cfr. M. A. MELÓN JimÉnEZ, Hacienda, comercio y contrabando en la frontera de Portugal (siglos XV-XVIII), Cáceres, 1999, pp. 193-230.

68. Pliego de 10 folios cosido al ramo $\mathrm{I}^{\circ}$. La carta del marqués de San Gil está firmada en Madrid, el 19 de agosto.

69. No se encuentran al final del proceso. La búsqueda en la sección de Real Acuerdo tampoco ha arrojado información al respecto. 
errores de identificación. ${ }^{70}$ Como era previsible, dados los antecedentes, de todos ellos sólo uno pudo ser detenido al proceder a la incautación de bienes: Sebastián García, un labrador de 60 años con ataques de epilepsia y problemas de ciática que no pudo escapar y evitar unirse a los Calavera en la cárcel de la villa. ${ }^{71}$ Pero más que la efícacia de la acción de la justicia, de cuyas limitaciones no cabe sorprenderse ahora habida cuenta de las confesiones del visitador de la renta de salinas y de las ponderaciones del intendente y del presidente del Consejo de Hacienda, la cuestión que se suscita es si la huida en masa de los acusados fue temporal o duradera, pues, como es evidente, en este último caso las consecuencias para la propia comunidad y para la administración señorial habrian sido mucho más dramáticas.

He tratado de resolver el problema mediante la consulta de los protocolos de los notarios del valle, pero, con la excepción de la cesión mancomunada de poderes a favor de José Vicente Guillem, escribiente de Valencia, por parte de los familiares de los reos culpados, en marzo de $1748,{ }^{72}$ no he hallado pista alguna sobre éstos, ni escrituras de transacción, fianza, declaración de dote, testamento o de cualquier otra indole que puedan demostrar el regreso - ni temprano ni tardio- a sus domicilios. Lo que, bien mirado, no significa que no lo hicieran, sino sólo que no dejaron huella, como por otro lado resulta lógico en fugitivos de la justicia. No obstante, hay datos que permiten conjeturar que el éxodo de los imputados no debió ser prolongado, cuando menos de la mayoría de ellos. Si se comparan las cuentas de administración del año 1749 , elaboradas por Silvestre Pérez Pastor-quien reemplazó a Clavijo como gobernador a comienzos de 1748 , pocos meses antes de que acaeciera la muerte de la duquesa María Ana de Borja-, con las que su predecesor había presentado una década antes (ambas reproducidas en las tablas adjuntas), podrá comprobarse que el crecimiento de la renta señorial en Cofrentes fue menor que el de las demás villas del estado, pero no tanto como la desaparición simultánea de una parte significativa de los hombres del pueblo - muchos de los cuales eran cabezas de familia- ${ }^{73}$ podría haber provocado.

En efecto, frente a un incremento global del $18 \%$-en valores nominales- entre 1739 y 1749 , que supone una medida de crecimiento muy similar a la del conjunto de

70. Por fin, los vecinos efectivamente culpados se dividen así: 10 culpados de fabricar sal, 26 de fabricarla y venderla, 20 de venderla solamente, más los 11 fabricantes involucrados en el homicidio del guardia.

71. Ramo $9^{\circ}, 21$ v. Ramo $8^{\circ}, 2$ r.

72. ARV, Protocolos de Tomás Carbonell Lázaro, 10622, 2 I r-28 v. Si hay registro contable del pago de luismos por ventas hechas en 1749 por tres de los procesados, pero de ello no se infiere necesariamente que estuvieran presentes en el acto.

73. Es difícil precisar cuántos de los reos eran cabezas de familia. Al menos 45 de ellos estaban casados, según se desprende del registro de propiedades incautadas y de la citada cesión mancomunada de poderes, aunque no todos tenían bienes propios. De hecho, cinco de éstos todavía vivían bajo el techo paterno. Sea como fuere, de acuerdo con la información que proporciona el juez Pardo de la Casta, a efectos fiscales y demográficos este grupo de prófugos representaba, aproximadamente, un tercio de los «vecinos» de la villa de Cofrentes, de manera que el golpe para la economía local habría sido muy fuerte si la huida hubiera sido duradera. 
la renta señorial de la nobleza valenciana en aquellos años, ${ }^{74}$ los ingresos que la señoría percibió en la villa de Cofrentes se elevaron tan sólo un 5,5\% (de 1.457 a 1.537 libras). Salvo Jalance, donde la renta aumentó también muy por debajo de la media (a pesar de lo cual dobló prácticamente la tasa de Cofrentes: el 10\%, de 1.432 a 1.576 libras), ${ }^{75}$ en el resto del valle el crecimiento del ingreso señorial durante ese período superó con holgura esa tasa: en Zarra el 15,3\% (de 1.215 a 1.401 libras); en Teresa el 17,8\% (de 2.186 a 2.576 libras); y un extraordinario 37,8 \% en Jarafuel (de 1.732 a 2.387 libras). En definitiva, si bien parece probable que la huida de los vecinos culpados fuese la causa principal del reducido aumento de la renta señorial en Cofrentes, cabe sospechar que muchos de ellos debieron tardar apenas unos meses -tal vez menos incluso- en volver a sus casas, a hurtadillas si se quiere, pues, de lo contrario, el exilio de tantos individuos laboral y fiscalmente activos habría generado pérdidas mucho mayores a la administración señorial. Desde este punto de vista, puede que las mismas redes de solidaridad vecinal que encubrieron con su silencio el contrabando de sal a gran escala entre 1746 y 1747 ocultaran también el retorno a la «normalidad» de los imputados, al menos de aquéllos que no guardaban relación directa con la muerte de Ginés García.

Por lo que se refiere a la condición social de los reos, el embargo de propiedades llevado a cabo en febrero de 1748 por el nuevo gobernador a instancia del fiscal Traver revela que 29 de los 67 acusados no poseían bienes propios (el 42,2\%) y que 9 de éstos (el $13 \%$ del total) eran «pobres de solemnidad», (al menos así fueron declarados por sus parientes). En otras palabras, más del $40 \%$ de los participantes en la red de contrabando no tenían otros medios para ganarse la vida que su sola fuerza de trabajo. Por otro lado, el registro practicado muestra que el grado de proletarización era mayor entre los que fabricaban la sal que entre los que la vendían. Las diferencias son ilustrativas: el $52 \%$ de quienes se limitaban a labores extractivas en los barrancos del Martinete y Tenesla carecían de bienes (11 de 21 productores). El porcentaje desciende al 42,3 $\%$ entre los expendedores que, de modo más o menos ocasional, fabricaban sal por su cuenta ( 11 de 26 culpados), y es todavía menor entre quienes únicamente vendían el género (el $32,6 \%$ de los 20 acusados de este delito), todo lo cual sugiere una división social del trabajo entre los vecinos implicados en el fraude. La pequeña extensión de las tierras poseídas por los fabricantes -sólo tres de los 21 productores tenían más de 5 tahúllas- apunta en esa misma dirección.

74. Cfr., J. A. CaTALÁ SANZ, op. cit., p. 226.

75. Los datos son demasiado fragmentarios para aventurar una hipótesis. Quizá el moderado aumento de la renta señorial en Jalance se debiera al impacto negativo de la riada de 1740 , que afectó especialmente a esta localidad (J.V. POVEDA MORA, op. cit., p. 75). Es posible, sin embargo, que el incremento de los ingresos en Jalance fuese mayor de lo dicho, ya que la suma de las distintas partidas consignadas por Silvestre Pérez Pastor, que es el valor que he empleado, no coincide con la cantidad global que anota en sus cuentas: 1.711 libras. Ignoro de dónde resulta esta cifra, pero, de ser cierta, el crecimiento habría sido superior al $19,4 \%$. 


\section{TABLA 1. DERECHOS DOMINICALES DEL VALLE DE COFRENTES EN 1739 (VALORES EN LIBRAS)}

\begin{tabular}{|c|c|c|c|c|c|}
\hline & Cofrentes & Jarafuel & Jalance & Teresa & Zarra \\
\hline Tienda & 100 & 160 & 50 & 183,5 & \multirow{2}{*}{56} \\
\hline Panadería & 6,5 & 8 & 6,5 & 9 & \\
\hline Menuderías & 120 & 106 & 144 & 172 & 111,5 \\
\hline Horno & 33 & 67 & 34 & 115,5 & 52 \\
\hline Pilón & 15 & 32,5 & 12 & 37,5 & 10,5 \\
\hline Molinos & -- & 69,8 & 454,6 & 300,7 & 257,4 \\
\hline Hierbas & 112 & 130 & 13,5 & 70 & 15 \\
\hline Trigo & 294,5 & 452,8 & 220,6 & 433,1 & 213,6 \\
\hline Cebada & 23,3 & 39,5 & 11,8 & 25,9 & 7,9 \\
\hline Centeno & 24,1 & 87,8 & 10,1 & 16,8 & 23,9 \\
\hline Panizo & 59,2 & 0,5 & 14,1 & 1,2 & -- \\
\hline Avena & 11,8 & 12,1 & 3,4 & 1,9 & 2,1 \\
\hline Adaza & 165,4 & 99,4 & 149,5 & 212,1 & 139 \\
\hline Pasas & 129,6 & -- & 8,2 & 1,9 & -- \\
\hline Vino & 55,5 & 94,6 & 104,7 & 248,2 & 115,5 \\
\hline Azafrán & 1,4 & 9,9 & 0,3 & -- & 0,6 \\
\hline Lana & 5,2 & 5,1 & -- & 11,5 & 2 \\
\hline Ganado & 97,3 & 70,9 & 17,1 & 67,5 & 17,5 \\
\hline Luismos & 40,9 & 102,5 & 45,5 & 55,8 & 68,4 \\
\hline Censos & 140,4 & 183,2 & 119,1 & 207,8 & 105,5 \\
\hline Borras & 21,4 & -- & 1,5 & -- & -- \\
\hline Otros & 0,4 & $-\cdots$ & 11 & 14,5 & 16,4 \\
\hline Total & 1457 & 1732 & 1432 & 2186 & 1215 \\
\hline
\end{tabular}

Fuente: AHN, Nobleza, Osuna, Leg. 988, 7.

Aparte de lo dicho, poco más puede colegirse de la información disponible. En virtud del grado de parentesco conocido de los procesados y conforme a lo expresado por algunos testigos, parece que en la trama de relaciones que se dibuja habrían ocupado una posición central unas cuantas familias: Julián Delgado, alias el Corista, tenido por uno de los principales fomentadores del contrabando, ${ }^{76}$ y su hermano Francisco; Pedro García, llamado el Tendero, y sus hijos Alonso, Juan y Pedro, a quienes se atribuyen cuantiosas ventas junto a Juan García, hijo del labrador preso Sebastián García; Andrés Landete, el Ayorín, casado con Ana María Villena; Esteban Villena y su hijo Juan; Miguel Navarro y su cuñado Antonio Landete, al que se suele mencionar asociado con Nicolás Muñoz; Juan Gómez y sus hijos Juan y José, emparentados con los Calavera,

76. En opinión de Diego García. (Ramo 4, 25 r). 
Nicolás y Pedro Navarro; José Alarcón, conocido como el Grillo mayor, padre de Juan, implicado en la muerte del guardia; los hermanos Cristóbal y José Gómez, «hijos del Curro», y alguna otra familia.

TABLA 2. DERECHOS DOMINICALES DEL VALLE DE COFRENTES EN 1749 (VALORES EN LIBRAS)

\begin{tabular}{|l|c|c|c|c|c|}
\hline & Cofrentes & Jarafuel & Jalance & Teresa & Zarra \\
\hline Tienda & 116 & 175 & 63 & 281,5 & \multirow{2}{*}{80} \\
\hline Panadería & 12 & 11 & 8,5 & 6,5 & 139 \\
\hline Menuderías & 140 & 136 & 135 & 220 & 93,5 \\
\hline Horno & 50 & 77 & 40 & 122,5 & 7,5 \\
\hline Pilón & 5,5 & 15 & 7 & 30 & 307,8 \\
\hline Molinos & -- & 71,9 & 620,5 & 387,6 & 8 \\
\hline Herbajes & 59 & 75 & 16 & 112 & 324,9 \\
\hline Trigo & 348,4 & 679,4 & 166,9 & 314,4 & 23,2 \\
\hline Cebada & 82,7 & 91,4 & 23,1 & 28,9 & 16,37 \\
\hline Centeno & 38,1 & 145,4 & 21,9 & 15,9 & 2,45 \\
\hline Panizo & 178,9 & 6,3 & 60,7 & 69 & 3,7 \\
\hline Avena & 30,4 & 11,6 & 14,2 & 4,9 & 121,5 \\
\hline Adaza & 69,7 & 392,2 & 152,7 & 282 & -- \\
\hline Pasas & 125 & -- & 5,2 & 24,6 & 95,93 \\
\hline Vino & 32 & 136,6 & 78,5 & 359 & 1,5 \\
\hline Azafrán & -- & -- & 1,1 & 6 & 1,8 \\
\hline Lana & 6 & 4,5 & 3,1 & 3,3 & -- \\
\hline Ganado & 53,6 & 42 & -- & 28,1 & 47,57 \\
\hline Luismos & 19,1 & 112,3 & 37,4 & 58,3 & 126,05 \\
\hline Censos & 160,5 & 204 & 121,5 & 207,2 & -- \\
\hline Borras & 10,5 & -- & -- & -- & -- \\
\hline Otros & -- & -- & -- & 13,5 & 1401 \\
\hline Total & 1537 & 2387 & $1576^{*}$ & 2576 & \\
\hline * La suma no coincide con la que presenta el contador de Jalance en su \\
informe: 1.711 libras & & & & \\
\hline Fuente: AHN & Noblezan & & & & \\
\hline
\end{tabular}

Fuente: AHN, Nobleza, Osuna, Leg. 988, 8.

Por último, cabe preguntarse qué fue de Luis Clavijo y Valenzuela. No es casual que después de haber desempeñado el cargo de gobernador del valle de Cofrentes durante más de diez años - desde antes que María Ana de Borja obtuviera la posesión del título ducal- fuese substituido por Silvestre Pérez Pastor a comienzos de 1748, justo un año después de que estallara la crisis de las salinas clandestinas. No obstante, dicha remoción no ha de interpretarse necesariamente como fruto de la pérdida de 
confianza de la duquesa de Gandía en su ministro, y mucho menos como una medida de castigo. Tal vez su salida del estado de Cofrentes fuese sólo una maniobra para facilitar la resolución del conflicto, a la que poco podía contribuir la rivalidad surgida entre el justicia mayor y el juez de comisión. De hecho, Clavijo fue a ocupar el puesto que su sucesor había dejado vacante en el marquesado de Llombai, donde se mantuvo durante un lustro. ${ }^{77}$ Razón de más, a tenor de la confianza que continuaba inspirando en la señoría, para rechazar la imputación de que toleró e incluso fomentó la aparición de la red de contrabando. 